Our Nature (2006)4:29-41

\title{
Traditional Grazing System and Seasonal Pasture Use in Upper Mustang, Nepal
}

\author{
A. Pokharel ${ }^{1}$ and M. Chetri ${ }^{2}$ \\ ${ }^{I}$ Institute of Forestry, Pokhara, Nepal \\ ${ }^{2}$ Hariyo Kharka, Pokhara, Nepal \\ Received: 24.09.2006; Accepted: 15.11.2006
}

\begin{abstract}
This research was undertaken from March 2006 to October 2006. The main aim of this research was to analysis the grazing system and seasonal pasture use in the selected VDCs of Upper Mustang. Ground truthing data of the two VDCs were collected to identify the seasonal pasture type and units. The pasture units were delineated in Topographic map by observing the pastures from vantage points. Key informants were consulted at field for this pupose. In addition, focal group discussion and interviews were taken with the village elite, herders and grazers for assessing grazing rights and use patterns. The result of this study reveals that the pastures lying in political boundary of one VDC are not necessarily being used by the same VDC. People have been practicing the traditional use right irrespective of the political boundary. On the basis of seasonal use, 7 different seasonal pasture types have been identified in the pastures used by Chhoser VDC and 6 different seasonal pasture types in Chuksang VDC. Livestock compositions in the two VDCs are different. The density of livestock in Chhosher VDC is 35.74 per sq. km. whereas it is only 15.69 per sq $\mathrm{km}$. in Chhuksang VDC. The grazing system and the use of resources are also different in these two pastures.
\end{abstract}

Keywords: Conservation, Grazing system, Pasture conflicts, Rangeland, Seasonal pasture use

\section{Introduction}

Upper Mustang has its own significance in terms of socio-cultural biological and geomorphologic diversity. Economically the people of Mustang rely on agro-pastoral system. However, agricultural production has been limited due to lack of sufficient water for irrigation and harsh climatic conditions (Kunwar, 2003). Animal husbandry is one of the main sources of earning livelihood. Grazing land comprises of $55.65 \%$ (Pokharel, 2006b). The average number of animals reared in 2002 in Upper Mustang was 36,503 (MIS, 2002). Cattle, yaks, dzos, sheep, goats, horses, mules and donkey are reared. Goat and sheep trading from China is also a common practice among the local population. The pastures available in the area are the only feeding source for the animals. So it is very important to make plans for the rational use of the rangeland so that sustainable use of the resources can be achieved. Indigenous rangeland management activities are practiced in Upper Mustang like rotational grazing, levying of fines for herders caught grazing outside their designated village grazing areas. But the traditional management system alone is not adequate to produce more forage in overgrazed and overpopulated rangeland (Thapa, 1990). Researchers have identified that overstocking (overgrazing) in the rangelands is the main factor causing deterioration of rangelands (Miller, 1996; Schaller and Gu, 1994; Wang et al., 2002). In 


\section{A. Pokhrel and M. Chetri / Our Nature (2006)4:29-41}

addition, in case of Upper Mustang, uprooting of shrubs of Caragana and Lonicera spp. instigated the degradation of the rangeland. According to Pokharel (2006), uprooting is practiced in $47.62 \%$ of the area and dung collection in $38.26 \%$ of the total area of pastures. Craig (1996) also stated that the traditional livestock management system in Upper Mustang tends to fall out side the carrying capacity concept. But till date no systematic study has been conducted to find out the exact area covered by the pastures of Upper Mustang. Unless the exact area covered by the pasture land is sorted out, accurate carrying capacity cannot be determined. Therefore, it is essential to conduct systematic research before proposing any interventions in the name of progress (Goldstein and Beall, 1990). The categorization of the rangelands based on seasonal use and grazing pressure in the study area provides essential base line information for developing future management strategy. The main aim of this paper is to analyse the seasonal pasture use and grazing rights of the two VDCs in Upper Mustang. This type of research has not been reported elsewhere and is a part of boarder research on pasture mapping in Upper Mustang.

\section{Study Area}

The present study was conducted in the two selected VDCs (Chhuksang and Chhosher VDCs) of Upper Mustang (Figure 1). Chhuksang VDC lies between 28 $47^{\prime} 51.11^{\prime \prime}$ $29^{\circ} 02^{\prime} 37.81^{\prime \prime} \mathrm{N}$ and $83^{\circ} 32^{\prime} 53.24^{\prime \prime}-84^{\circ} 03^{\prime} 6.57^{\prime \prime}$

$\mathrm{E}$ whereas Chhosher VDC lies between

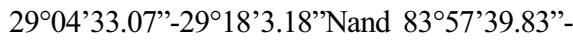
$84^{\circ} 12^{\prime} 10.60^{\prime \prime} \mathrm{E}$ in Mustang district. Chhuksang VDC receives more precipitation compared to Chhosher VDC in terms of rainfall. The climate of the area is cold, desiccated by strong winds and high solar radiation. The climate is sub-alpine, and has a maximum temperature of $18^{\circ} \mathrm{C}$ in July and a minimum of $-12^{\circ} \mathrm{C}$, in January. The whole area remains under snow for 4 - 5 months from November to March. Total annual rainfall is less than $200 \mathrm{~mm}$ and more than half of the total precipitation occurs as snow during the winter months (Chetri and Gurung, 2004).

\section{Materials and methods}

The pasture units (patches of pasture with specific name given by locals) used by the VDCs were identified by observing from the vantage points and the corresponding boundaries were delineated in the Topographic map published by the survey department of HMG, Nepal in 2001. Local names of the units based on key informant's information were recorded. The information so obtained was cross checked with reference to 3-D model of the VDC prepared by the project. Map of the pasture units was prepared using the GIS softwares; Cartalinx, Arc view 3.2 and Arc GIS. The boundary of the pasture units delineated on topographic map in the field was digitized on screen using digitized topographic map of the area from secondary source in Arc view 3.2. It was then imported in Cartalinx and the map was edited and finalized. Again by exporting it to Arc view 3.2 and Arc GIS, the attributes of each of the pasture units gathered in field were joined and area calculation was done. Area calculation of the pasture units was done following the political boundary and the use right of the VDCs. Information regarding the pasture rights and use patterns were collected through focal group discussion and key informants.

\section{Results and discussion \\ Traditional Grazing System}

People in Upper Mustang have been practicing their own traditional rotational 
A. Pokhrel and M. Chetri / Our Nature (2006)4: 29-41

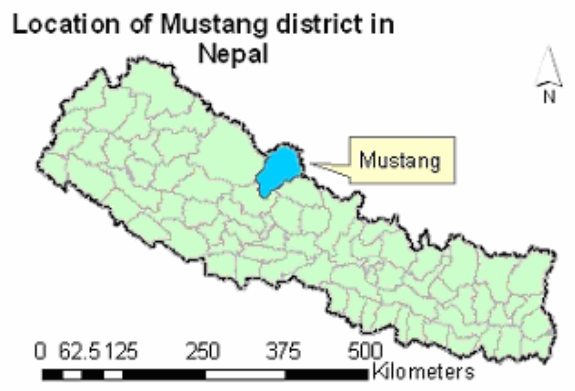

\section{Village Development Committees (VDCs) of Upper Mustang}

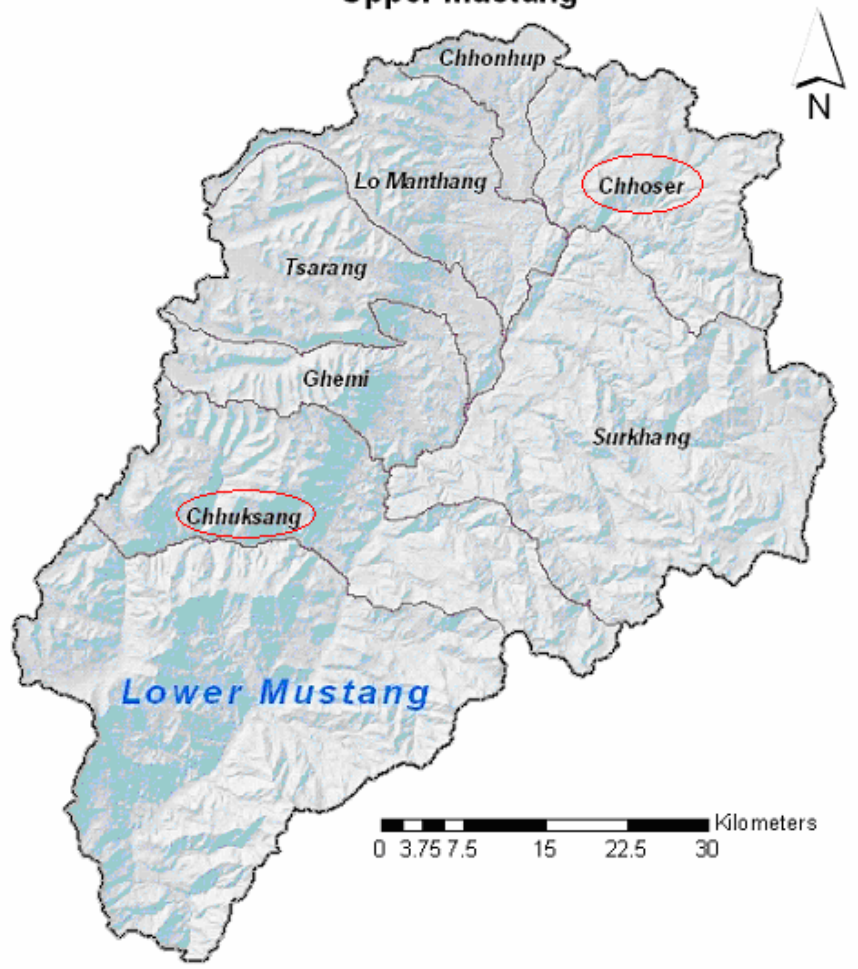

Figure 1. Location of the VDCs of Upper Mustang 
A. Pokhrel and M. Chetri / Our Nature (2006)4: 29-41

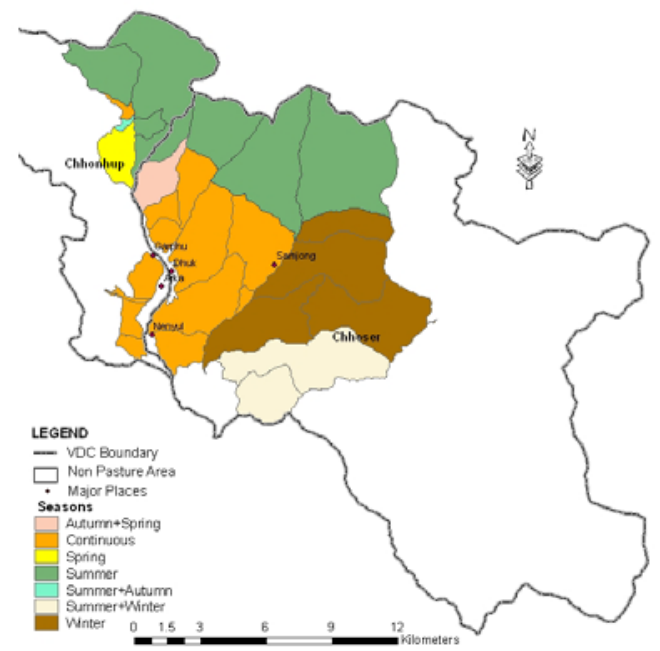

Figure 2 Seasonal pasture units used by Chhosher VDC

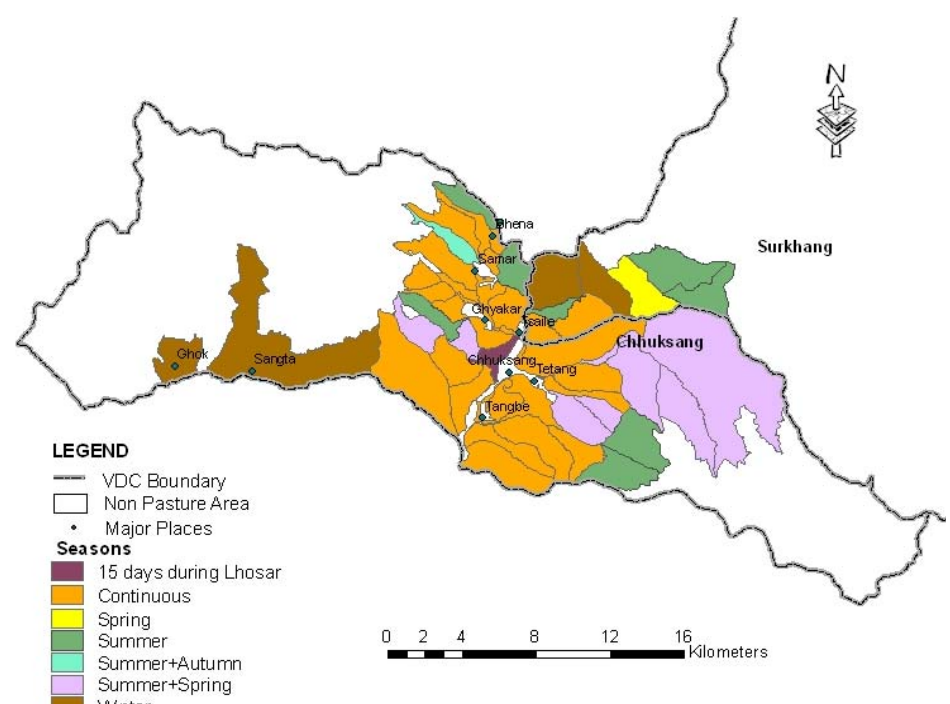

Figure 3 Seasonal pasture units used by Chuksang VDC 
A. Pokhrel and M. Chetri / Our Nature (2006)4: 29-41

Table 1. Seasonal pasture types used by VDCs

\begin{tabular}{|c|c|c|c|c|c|c|}
\hline \multirow{2}{*}{ Seasonal pasture type } & \multicolumn{2}{|c|}{ Chhosher } & \multicolumn{2}{|c|}{ Chhuksang } & \multirow{2}{*}{$\begin{array}{l}\text { Total seasonal } \\
\text { pasture area of } \\
\text { two VDCs } \\
(\text { Area } s q \mathrm{~km})\end{array}$} & \multirow[b]{2}{*}{$\%$} \\
\hline & $\begin{array}{l}\text { Area (sq } \\
\text { km) }\end{array}$ & $\%$ & Area (sq km) & $\%$ & & \\
\hline 15 days during Lhosar* & - & & 2.06 & 0.80 & 2.06 & 0.48 \\
\hline Autumn+Spring & 3.79 & 2.20 & - & - & 3.79 & 0.88 \\
\hline Continuous & 41.97 & 24.36 & 102.39 & 39.89 & 144.36 & 33.65 \\
\hline Spring & 3.59 & 2.08 & 6.01 & 2.34 & 9.6 & 2.24 \\
\hline Summer & 65.65 & 38.11 & 35.51 & 13.83 & 101.16 & 23.58 \\
\hline Summer+Autumn & 0.26 & 0.15 & 2.71 & 1.06 & 2.97 & 0.69 \\
\hline Summer+Spring & - & - & 64.55 & 25.15 & 64.55 & 15.05 \\
\hline Summer+Winter & 18.46 & 10.72 & - & - & 18.46 & 4.30 \\
\hline Winter & 38.56 & 22.38 & 43.45 & 16.93 & 82.01 & 19.12 \\
\hline Total & 172.28 & 100.00 & 256.68 & 100.00 & 428.96 & 100.00 \\
\hline
\end{tabular}

* Lhosar festival is observed in January.

Table 2. Area and livestock density on the pastures

\begin{tabular}{|c|c|c|c|c|c|c|c|c|}
\hline SN. & VDCs & $\begin{array}{l}\text { VDC } \\
\text { Area } \\
(\mathbf{s q} \\
\text { km) }\end{array}$ & $\begin{array}{l}\text { Pasture } \\
\text { area } \\
\text { within } \\
\text { the VDC } \\
(\mathrm{sq} \mathrm{km})\end{array}$ & $\begin{array}{l}\% \quad \text { of } \\
\text { pasture } \\
\text { area in } \\
\text { VDC }\end{array}$ & $\begin{array}{l}\text { Area of } \\
\text { pasture } \\
\text { used by the } \\
\text { VDC (sq } \\
\text { km) }\end{array}$ & $\begin{array}{l}\% \text { of } \\
\text { pasture } \\
\text { area used } \\
\text { by the } \\
\text { VDC }\end{array}$ & $\begin{array}{l}\text { Livestock } \\
\text { number }\end{array}$ & $\begin{array}{l}\text { Livestock } \\
\text { density } \\
\text { (number/sq } \\
\text { km) }\end{array}$ \\
\hline 1 & Chhoser & 345.67 & 326.79 & 94.54 & 172.28 & 12.06 & 6,157 & 35.74 \\
\hline 2 & Chuksang & 491.74 & 217.25 & 44.18 & 256.68 & 17.97 & 4,028 & 15.69 \\
\hline
\end{tabular}

Table 3. VDC areas and other users of the pastures

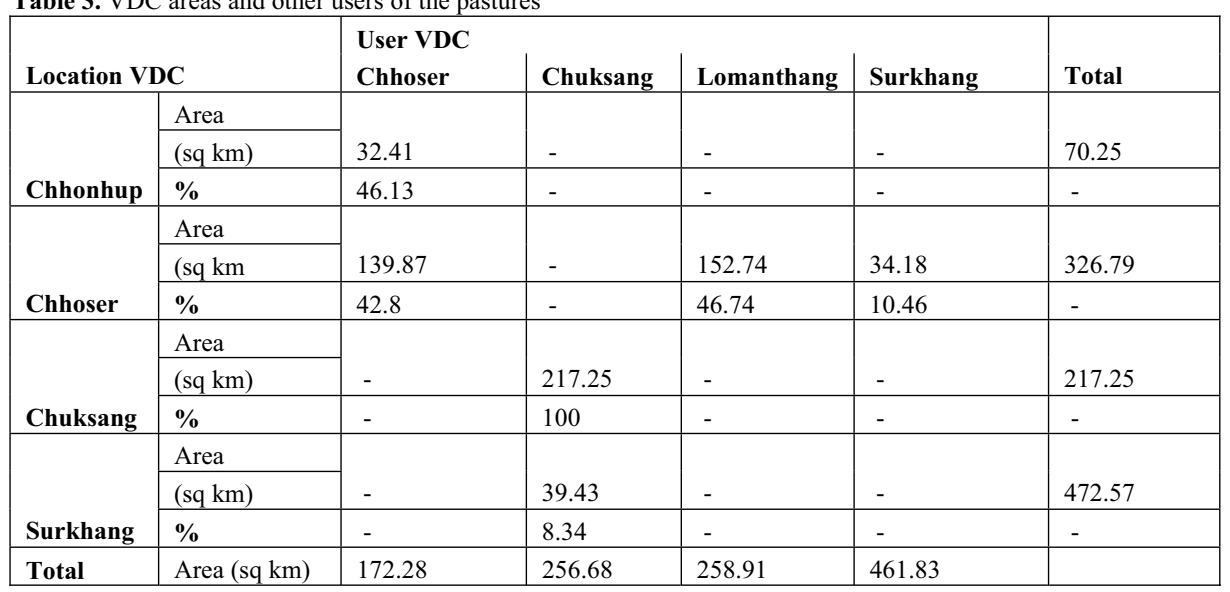




\section{A. Pokhrel and M. Chetri / Our Nature (2006)4:29-41}

grazing practices. Each VDC has their own system and a set of rules and rights for the use of pastures that has been set already from last few generations. Mukhiya system still prevails in the area. Mukhiya is known as Dhongba in local language. The role and responsibility of the Dhongba is being defined within the set of rules provided by their forefathers. The tenure of the Dhongba is generally of one year and recruited according to rank, based on seniority in the village. Mukhiya has the rights in leveying taxes for grazing in the pastures. Depending on the livestock types, taxes vary and the herders/owners have to pay on monthly or annual basis. Rotational grazing rules exist in all the VDCs. However they are not strictly followed in some VDCs by the villagers. But such rules are strictly followed by the nomads. Nomadism is an age old practice existing in the high altitude pastures of Upper Mustang. Presently 9 families of nomads are residing in the area. Total population is 44 with an average household size of 5. They move to different pastures in different seasons: summer, autumn, winter and spring. Nomads do not need to pay any tax to the VDC for using the rangeland but they are not allowed to use winter pasture (Pokharel 2006a). Their livestock freely roam in the pastures without any herders and are monitored at least once in a month. Herders who use the pasture of other VDC without any permission from the Dhongba of the concerned, have to face penalty as decided by the Dhongba. But the punishment is relatively less severe in case of people of same village. In this regard the traditional grazing system is becoming weak day by day. Traditional rotational grazing system if followed seriously can be an effective tool for maintaining the rangeland health and biodiversity that thrive in the area.

\section{Pasture units and seasonal pasture}

On the basis of seasonal use, nine different seasonal pasture types have been identified in the study area (Table 1). In Chhosher VDC, the highest proportion (65.65\%) of the pasture is used during the summer (65.65\%). In comparison to other pasture use patterns least area are reserved for spring and summer plus autumn. In comparison to summer pasture area, the winter pasture is low. This has caused a serious problem in the food shortage for livestock during the winter. Caragana and Lonicera spp. are uprooted by the villagers to meet the energy demands. This has also reduced the bush layer in the pasture which is the food for sheep and goats for the winter. In case of Chhuksang VDC, the highest proportion of the pasture is open to all seasons $(39.89 \%)$. It was interesting to note here that one pasture unit of Chuksang VDC is used only for 15 days during the Lhosar festival which is observed in January. Of the total area of the two VDCs, higher proportion of the pasture are utilized for continuous grazing $(33.65 \%)$ and a low proportion (19.12\%) are utilized for the winter grazing. Looking at the overall area of the pasture of Upper Mustang (1428.33 sq km), Pokharel (2006b) estimated that the highest proportion is shared by the summer pasture i.e. $40.97 \%$ followed by winter pasture, $21.96 \%$. Overall assessment of the pasture also indicates that there is a shortage of winter pasture area in upper Mustang. However, the utilization and the division of the pasture vary according to VDCs.

\section{Pasture used by Chhosher VDC vs. Chhuksang VDC}

In Chhoser VDCs, bulk of the livestock population comprises of sheep and goats. The population of yaks is very low in 


\section{A. Pokhrel and M. Chetri / Our Nature (2006)4:29-41}

comparision to other livestock. But in Chhuksang VDC, Yaks are not reared by the local communities. Table 2 represents the livestock density (number/sq $\mathrm{km}$ ) of the two VDCs. In comparison to area, higher number of livestock is reared by the local people of Chhosher VDC. This is mainly due to limited agricultural land to sustain. In addition, the quality of pasture land in Chhosher VDC is as good as majority of the pastures abutting to the border of Tibetan Autonomous Region, China. Livestock distribution and types also vary among the VDCs. Pokharel (2006b) estimated the average livestock density in the whole pastures of seven VDCs in Upper Mustang is 26.64 per sq $\mathrm{km}$.

Chhoser VDC uses 29 pasture units (Figure 2). The sum total of the pasture land in the political boundary of this VDC is $326.79 \mathrm{sq} \mathrm{kms}$ which constitutes $94.54 \%$ of the VDC area. Of this area, $42.80 \%$ is used by Chhoser VDC, 46.74 by Lo Manthang VDC and $10.46 \%$ by Surkhang VDC (Table 3). The total area covered by the pasture used by the VDC is $172.28 \mathrm{sq} \mathrm{kms}$ which account for $12.06 \%$ of the total area of the pastures of Upper Mustang. The livestock density is 35.74 per sq. $\mathrm{km}$ (see Table 2). Along with pasture within the VDC boundary, it also uses some areas of Chhonhup VDC (see Figure 2 and Table 3).

Chuksang VDC uses 51 pasture units (Figure 3). The total area covered by the pasture used by the VDC is $256.68 \mathrm{sq} \mathrm{kms}$ which accounts to $17.97 \%$ of the total area of the pastures of Upper Mustang (Pokharel, 2006b). The total area of the pasture land within the boundary of this VDC is 217.25 sq $\mathrm{kms}$ which constitutes $44.18 \%$ of the VDC area and the livestock density is 15.69 per sq. $\mathrm{km}$ (see Table 2). Beside the pasture lying within the VDC, it uses some area of Surkhang VDC (see Figure 3 and Table 3).

Altogether 80 different pasture units have been recorded to be used by the two VDCs. People have been following the traditional use right irrespective of the political boundary in using the pastures. So a number of pasture units lying within these VDCs are used by other VDCs. Description of each of the units is given in Annex 1 .

\section{Conclusion}

The rangeland in Upper Mustang region is unique in the sense that it is directly correlated with the annual climatic patterns. Timely rainfall and snowfall always make rangeland visibly green and productive. However, within a week the pasture may get changed if the northern wind blows continuously for few days. Highly variable climate makes the area more and more fragile and this has direct impact on the rangelands. In addition, the weakening of the traditional rotational practices and uprooting of shrubs for fulfilling energy requirements is another crucial issue. The use of pasture varies according to VDCs and has been practicing the traditional use right irrespective of the political boundary. Pastures lying in political boundary of one VDC are not necessarily being used by the same VDC. On the basis of seasonal use, nine different seasonal pasture types have been identified. Future studies which will document the carrying capacity for ensuring sustainable range production and biodiversity conservation are felt necessary.

\section{Acknowledgements}

We would like to express thanks to all the team of Lo Manthang Unit Conservation Office for their hard work and hospitality during the 


\section{A. Pokhrel and M. Chetri / Our Nature (2006)4:29-41}

Annex 1: Pasture unit profile of Chhoser and Chhuksang VDC

Pasture units used by Chhoser VDC

\begin{tabular}{|c|c|c|c|c|c|c|}
\hline SN & $\begin{array}{ll}\begin{array}{l}\text { Pasture } \\
\text { (Local name) }\end{array} & \text { Name } \\
\end{array}$ & $\begin{array}{l}\text { Location } \\
\text { VDC }\end{array}$ & Total area & $\begin{array}{l}\text { Grazing } \\
\text { season }\end{array}$ & $\begin{array}{l}\text { User } \\
\text { VDC } \\
\end{array}$ & $\begin{array}{l}\text { Animal type using the } \\
\text { pasture }\end{array}$ \\
\hline 1 & SAKAU & Chhoser & $3.41 \mathrm{Km}^{2}$ & Continuous & Chhoser & $\begin{array}{l}\text { Lulu, Goat, Sheep, } \\
\text { Donkey }\end{array}$ \\
\hline 2 & GHOMBO LHA & Chhoser & $8.57 \mathrm{Km}^{2}$ & Continuous & Chhoser & Lulu, Goat, Sheep \\
\hline 3 & BHUMBA RAHA & Chhoser & $8.88 \mathrm{Km}^{2}$ & Continuous & Chhoser & Goat, Sheep, Horse \\
\hline 4 & KIMBU & Chhoser & $8.02 \mathrm{Km}^{2}$ & Continuous & Chhoser & Goat, Sheep, Horse \\
\hline 5 & CHHEGAM & Chhoser & $14.45 \mathrm{Km}^{2}$ & Summer & Chhoser & Goat, Sheep, Horse \\
\hline 6 & NGILE KARCHUNG & Chhoser & $19.02 \mathrm{Km}^{2}$ & Summer & Chhoser & Goat, Sheep, Horse \\
\hline 7 & KAMLUNG & Chhoser & $4.70 \mathrm{Km}^{2}$ & Winter & Chhoser & Goat, Sheep, Horse \\
\hline 8 & SETE RHAWA & Chhoser & $11.88 \mathrm{Km}^{2}$ & Winter & Chhoser & Goat, Sheep, Horse \\
\hline 9 & TUNG & Chhoser & $9.73 \mathrm{Km}^{2}$ & Winter & Chhoser & Goat, Sheep, Horse \\
\hline 10 & JHIMJHANG & Chhoser & $12.89 \mathrm{Km}^{2}$ & $\begin{array}{l}\text { Winter \& } \\
\text { Summer }\end{array}$ & Chhoser & Goat, Sheep, Horse \\
\hline 11 & MAATHI GHYAMO & Chhoser & $0.53 \mathrm{Km}^{2}$ & Continuous & Chhoser & $\begin{array}{l}\text { Lulu, Goat, Sheep, } \\
\text { Horse }\end{array}$ \\
\hline 12 & SEUTHANG & Chhoser & $12.25 \mathrm{Km}^{2}$ & Winter & Chhoser & Goat, Sheep, Horse \\
\hline 13 & RHAJUNG & Chhoser & $5.57 \mathrm{Km}^{2}$ & $\begin{array}{l}\text { Winter \& } \\
\text { Summer }\end{array}$ & Chhoser & Goat, Sheep, Horse \\
\hline 14 & CHHYUKU MHAU & Chhoser & $7.31 \mathrm{Km}^{2}$ & Summer & Chhoser & Goat, Sheep, Horse \\
\hline 15 & CHHOYALING & Chhoser & $1.54 \mathrm{Km}^{2}$ & Continuous & Chhoser & Lulu, Goat, Sheep \\
\hline 16 & GIBU CHHIRE & Chhoser & $1.61 \mathrm{Km}^{2}$ & Continuous & Chhoser & $\begin{array}{l}\text { Lulu, Goat, Sheep, } \\
\text { Horse }\end{array}$ \\
\hline 17 & SALINDE & Chhoser & $3.75 \mathrm{Km}^{2}$ & Continuous & Chhoser & Goat, Sheep \\
\hline 18 & BHAAMAMO & Chhoser & $3.79 \mathrm{Km}^{2}$ & $\begin{array}{l}\text { Autumn \& } \\
\text { Spring }\end{array}$ & Chhoser & Goat, Sheep, Horse \\
\hline $19^{*}$ & KHUKYU & Chhoser & $1.98 \mathrm{Km}^{2}$ & Summer & Chhoser & Goat, Sheep, Horse \\
\hline $19^{*}$ & KHUKYU & Chhonhup & $1.58 \mathrm{Km}^{2}$ & Summer & Chhoser & Goat, Sheep, Horse \\
\hline 20 & $\begin{array}{l}\text { PHORA } \\
\text { GHYAPCHA PANG }\end{array}$ & Chhonhup & $6.16 \mathrm{Km}^{2}$ & Summer & Chhoser & $\begin{array}{l}\text { Yak, Goat, Sheep, } \\
\text { Horse }\end{array}$ \\
\hline 21 & $\begin{array}{l}\text { CHHORTEN } \\
\text { MARKOK }\end{array}$ & Chhonhup & $13.98 \mathrm{Km}^{2}$ & Summer & Chhoser & Yak, Goat, Sheep \\
\hline 22 & $\begin{array}{l}\text { CHHYAMKI } \\
\text { THANKA }\end{array}$ & Chhonhup & $1.18 \mathrm{Km}^{2}$ & Summer & Chhoser & $\begin{array}{l}\text { Yak, Goat, Sheep, } \\
\text { Horse }\end{array}$ \\
\hline 23 & $\begin{array}{l}\text { KYUCHHU } \\
\text { NAAMA }\end{array}$ & Chhonhup & $0.54 \mathrm{Km}^{2}$ & Continuous & Chhoser & $\begin{array}{l}\text { Yak, Goat, Sheep, } \\
\text { Horse }\end{array}$ \\
\hline 24 & $\begin{array}{l}\text { NAMA } \\
\text { DHONGDHONG }\end{array}$ & Chhonhup & $0.26 \mathrm{Km}^{2}$ & $\begin{array}{l}\text { Summer \& } \\
\text { Autumn }\end{array}$ & Chhoser & Goat, Sheep, Horse \\
\hline 25 & JHOGLE & Chhonhup & $3.59 \mathrm{Km}^{2}$ & Spring & Chhoser & $\begin{array}{l}\text { Yak, Goat, Sheep, } \\
\text { Horse }\end{array}$ \\
\hline 26 & $\begin{array}{l}\text { GHYALANG } \\
\text { BHAAMA }\end{array}$ & Chhonhup & $1.02 \mathrm{Km}^{2}$ & Continuous & Chhoser & Lulu, Goat, Sheep \\
\hline 27 & $\begin{array}{l}\text { MAATANG } \\
\text { RINGMA }\end{array}$ & Chhonhup & $1.51 \mathrm{Km}^{2}$ & Continuous & Chhoser & $\begin{array}{l}\text { Lulu, Goat, Sheep, } \\
\text { Donkey }\end{array}$ \\
\hline 28 & DHEELU KHOLA & Chhonhup & $0.33 \mathrm{Km}^{2}$ & Continuous & Chhoser & Lulu, Goat, Sheep \\
\hline 29 & KIRI & Chhonhup & $2.25 \mathrm{Km}^{2}$ & Continuous & Chhoser & Lulu, Goat, Sheep \\
\hline
\end{tabular}


A. Pokhrel and M. Chetri / Our Nature (2006)4:29-41

Pasture units lying in Chhoser VDC but used by other VDCs

\begin{tabular}{|c|c|c|c|c|c|c|}
\hline $\begin{array}{l}\mathbf{S} \\
\mathbf{N}\end{array}$ & $\begin{array}{l}\text { Pasture Name (Local } \\
\text { name) }\end{array}$ & Total area & $\begin{array}{l}\text { Grazing } \\
\text { season }\end{array}$ & User VDC & $\begin{array}{l}\text { Animal } \\
\text { type using } \\
\text { the pasture }\end{array}$ & Remarks \\
\hline 1 & MARCHUNG (Sakau) & $2.37 \mathrm{Km}^{2}$ & Winter & Lo Manthang & $\begin{array}{l}\text { Goat, sheep, } \\
\text { horse, lulu } \\
\text { cow }\end{array}$ & - \\
\hline 2 & $\begin{array}{l}\text { DHARCHONGOMB } \\
\text { A }\end{array}$ & $3.91 \mathrm{Km}^{2}$ & Winter & Lo Manthang & Goat, sheep & - \\
\hline 3 & RHIJIPHUWA & $24.46 \mathrm{Km}^{2}$ & Winter & Lo Manthang & $\begin{array}{l}\text { Yak, goat, } \\
\text { sheep }\end{array}$ & $\begin{array}{l}\text { Political boundary of } \\
\text { Chhoser VDC but Lo } \\
\text { Manthang nomads are } \\
\text { using }\end{array}$ \\
\hline 4 & CHUJUNG (Yaja) & $52.08 \mathrm{Km}^{2}$ & Summer & Lo Manthang & $\begin{array}{l}\text { Yak, goat, } \\
\text { sheep }\end{array}$ & $\begin{array}{l}\text { Political boundary of } \\
\text { Chhoser VDC but Lo } \\
\text { Manthang nomads are } \\
\text { using }\end{array}$ \\
\hline 5 & MUKCHUNG & $34.08 \mathrm{Km}^{2}$ & Summer & Lo Manthang & Yak & $\begin{array}{l}\text { Political boundary of } \\
\text { Chhoser VDC but Lo } \\
\text { Manthang nomads are } \\
\text { using }\end{array}$ \\
\hline 6 & MARCHA & $1.75 \mathrm{Km}^{2}$ & Spring & Lo Manthang & $\begin{array}{l}\begin{array}{l}\text { Yak, goat, } \\
\text { sheep }\end{array} \\
\end{array}$ & - \\
\hline 7 & DHALUNG & $34.09 \mathrm{Km}^{2}$ & Summer & Lo Manthang & & $\begin{array}{l}\text { Political boundary of } \\
\text { Chhoser VDC, used by } \\
\text { Chhoser horses as well, } \\
\text { traders' route, conflict } \\
\text { between Samjung and } \\
\text { Nomads of Lo } \\
\text { Manthang and also } \\
\text { Chinese nomads }\end{array}$ \\
\hline 8 & MUKCHUNG & $13.58 \mathrm{Km}^{2}$ & Summer & Surkhang & Yak & - \\
\hline 9 & TAAPKE PEKANG & $15.41 \mathrm{Km}^{2}$ & Summer & Surkhang & Yak, Dzopa & - \\
\hline 10 & PANGA & $4.06 \mathrm{Km}^{2}$ & Summer & Surkhang & Yak & - \\
\hline
\end{tabular}

Pasture Units used by Chuksang VDC

\begin{tabular}{|l|l|l|l|l|l|l|}
\hline $\begin{array}{l}\text { S } \\
\text { N }\end{array}$ & $\begin{array}{l}\text { Pasture Name } \\
\text { (Local name) }\end{array}$ & $\begin{array}{l}\text { Location } \\
\text { VDC }\end{array}$ & Total area & $\begin{array}{l}\text { Grazing } \\
\text { season }\end{array}$ & $\begin{array}{l}\text { Animal type } \\
\text { using } \\
\text { pasture }\end{array}$ & Remarks \\
\hline 1 & $\begin{array}{l}\text { CHHYUME } \\
\text { DANDA }\end{array}$ & Chuksang & $7.19 \mathrm{Km}^{2}$ & Continuous & $\begin{array}{l}\text { Lulu, Goat, } \\
\text { Sheep, Horse, } \\
\text { Mule, Dzopa }\end{array}$ & $\begin{array}{l}\text { Keep goth in } \\
\text { summer }\end{array}$ \\
\hline 2 & $\begin{array}{l}\text { CHHYUME } \\
\text { THANKA }\end{array}$ & Chuksang & $4.27 \mathrm{Km}^{2}$ & Continuous & $\begin{array}{l}\text { Lulu, Goat, } \\
\text { Sheep, Horse, } \\
\text { Mule, Dzopa }\end{array}$ & $\begin{array}{l}\text { Keep goth in } \\
\text { summer }\end{array}$ \\
\hline 3 & SANO CHHYUME & Chuksang & $6.64 \mathrm{Km}^{2}$ & Continuous & $\begin{array}{l}\text { Lulu, Goat, } \\
\text { Sheep, Horse, } \\
\text { Mule, Dzopa in Winter. Jhong }\end{array}$ \\
$\begin{array}{l}\text { Goth Muktinath VDC } \\
\text { also uses this pasture. }\end{array}$ \\
\hline 4 & $\begin{array}{l}\text { THULO } \\
\text { CHHYUME } \\
\text { (MIULA) }\end{array}$ & Chuksang & $3.57 \mathrm{Km}^{2}$ & Continuous & $\begin{array}{l}\text { Lulu, Goat, } \\
\text { Sheep, Horse, } \\
\text { Mule, Dzopa }\end{array}$ & $\begin{array}{l}\text { Goth in Winter. } \\
\text { Jhong of Muktinath } \\
\text { VDC also uses this }\end{array}$ \\
\hline
\end{tabular}


A. Pokhrel and M. Chetri / Our Nature (2006)4:29-41

\begin{tabular}{|c|c|c|c|c|c|c|}
\hline & & & & & & pasture. \\
\hline 5 & NHERIK DANDA & Chuksang & $5.70 \mathrm{Km}^{2}$ & Summer & $\begin{array}{l}\text { Lulu, Goat, } \\
\text { Sheep, Horse, } \\
\text { Mule, Dzopa }\end{array}$ & $\begin{array}{l}\text { Jhong also uses this } \\
\text { pasture. Litting fire } \\
\text { is not allowed while } \\
\text { keeping goth. }\end{array}$ \\
\hline 6 & PUMCHI DANDA & Chuksang & $2.56 \mathrm{Km}^{2}$ & Continuous & $\begin{array}{l}\text { Goat, Sheep, } \\
\text { Horse, Mule, } \\
\text { Dzopa }\end{array}$ & $\begin{array}{l}\text { Tetang also uses but } \\
\text { goth keeping is not } \\
\text { allowed. }\end{array}$ \\
\hline 7 & $\begin{array}{l}\text { KYONJEGHANG } \\
\text { A }\end{array}$ & Chuksang & $4.04 \mathrm{Km}^{2}$ & Continuous & $\begin{array}{l}\text { Lulu, Goat, } \\
\text { Sheep, Horse, } \\
\text { Mule, Dzopa }\end{array}$ & - \\
\hline 8 & DHOBANANG & Chuksang & $0.61 \mathrm{Km}^{2}$ & Continuous & $\begin{array}{l}\text { Goat, Sheep, } \\
\text { Horse, Mule, } \\
\text { Dzopa }\end{array}$ & - \\
\hline 9 & CHUMBAK & Chuksang & $3.63 \mathrm{Km}^{2}$ & $\begin{array}{l}\text { Summer+Spr } \\
\text { in }\end{array}$ & $\begin{array}{l}\text { Goat, Sheep, } \\
\text { Horse, Mule, } \\
\text { Dzopa }\end{array}$ & - \\
\hline 10 & TOMAGHYAM & Chuksang & $4.23 \mathrm{Km}^{2}$ & Continuous & $\begin{array}{l}\text { Lulu, Goat, } \\
\text { Sheep, Horse, } \\
\text { Mule, Dzopa }\end{array}$ & - \\
\hline 11 & IKJUPHU & Chuksang & $2.96 \mathrm{Km}^{2}$ & Summer & $\begin{array}{l}\text { Lulu, Goat, } \\
\text { Sheep, Horse, } \\
\text { Mule, Dzopa }\end{array}$ & $\begin{array}{l}\text { Ghyakar can also use } \\
\text { for grazing but goth } \\
\text { with fire is not } \\
\text { allowed. Ghyakar uses } \\
\text { for dung collection. }\end{array}$ \\
\hline 12 & KHERKU & Chuksang & $2.06 \mathrm{Km}^{2}$ & $\begin{array}{l}\text { Summer+Spr } \\
\text { ing }\end{array}$ & $\begin{array}{l}\text { Lulu, Goat, } \\
\text { Sheep, Horse, } \\
\text { Mule, Dzopa }\end{array}$ & - \\
\hline 13 & $\begin{array}{l}\text { KHOLAPARI } \\
\text { GOTH / BAN }\end{array}$ & Chuksang & $3.86 \mathrm{Km}^{2}$ & Continuous & $\begin{array}{l}\text { Lulu, Goat, } \\
\text { Sheep, Horse, } \\
\text { Mule, Dzopa }\end{array}$ & - \\
\hline 14 & GHELDHUNBUK & Chuksang & $13.84 \mathrm{Km}^{2}$ & Continuous & $\begin{array}{l}\text { Lulu, Goat, } \\
\text { Sheep, Horse, } \\
\text { Mule, Dzopa }\end{array}$ & - \\
\hline 15 & JHONG & Chuksang & $2.06 \mathrm{Km}^{2}$ & $\begin{array}{ll}15 & \text { days } \\
\text { during } & \\
\text { Lhosar } & \\
\end{array}$ & $\begin{array}{l}\text { Lulu, Goat, } \\
\text { Sheep, Horse, } \\
\text { Mule, Dzopa }\end{array}$ & - \\
\hline 16 & GHUNSA & Chuksang & $26.05 \mathrm{Km}^{2}$ & Winter & Goat, Sheep & - \\
\hline 17 & GHOK & Chuksang & $4.97 \mathrm{Km}^{2}$ & Winter & $\begin{array}{l}\text { Yak, Lulu, } \\
\text { Goat, Sheep, } \\
\text { Horse, Mule, } \\
\text { Dzopa }\end{array}$ & $\begin{array}{l}\text { Sangta village shifts } \\
\text { here in winter. Way } \\
\text { to Dolpo. }\end{array}$ \\
\hline 18 & NHARIK & Chuksang & $6.48 \mathrm{Km}^{2}$ & Summer & $\begin{array}{l}\text { Lulu, Goat, } \\
\text { Sheep, Horse, } \\
\text { Mule, Dzopa }\end{array}$ & $\begin{array}{l}\text { Jhong also uses } \\
\text { occasionaly for } \\
\text { grazing but keeping } \\
\text { goth and litting fire is } \\
\text { not allowed. Nomads } \\
\text { used in the past. }\end{array}$ \\
\hline 19 & GHEYUK & Chuksang & $2.28 \mathrm{Km}^{2}$ & $\begin{array}{l}\text { Summer }+ \\
\text { Spring }\end{array}$ & $\begin{array}{l}\text { Lulu, Goat, } \\
\text { Sheep, Horse, } \\
\text { Mule, Dzopa }\end{array}$ & Goth is in cave \\
\hline
\end{tabular}


A. Pokhrel and M. Chetri / Our Nature (2006)4:29-41

\begin{tabular}{|c|c|c|c|c|c|c|}
\hline 20 & KYUHEN DANDA & Chuksang & $5.20 \mathrm{Km}^{2}$ & $\begin{array}{l}\text { Summer + } \\
\text { Spring }\end{array}$ & $\begin{array}{l}\text { Lulu, Goat, } \\
\text { Sheep, Horse, } \\
\text { Mule, Dzopa }\end{array}$ & - \\
\hline 21 & KYUTEN & Chuksang & $2.52 \mathrm{Km}^{2}$ & Continuous & $\begin{array}{l}\text { Lulu, Goat, } \\
\text { Sheep, Horse, } \\
\text { Mule, Dzopa }\end{array}$ & - \\
\hline 22 & $\begin{array}{l}\text { NUNKHANI } \\
\text { DANDA }\end{array}$ & Chuksang & $4.74 \mathrm{Km}^{2}$ & Continuous & $\begin{array}{l}\text { Lulu, Goat, } \\
\text { Sheep, Horse, } \\
\text { Mule, Dzopa }\end{array}$ & - \\
\hline 23 & HASISICHYA & Chuksang & $7.70 \mathrm{Km}^{2}$ & $\begin{array}{l}\text { Summer+Spr } \\
\text { ing }\end{array}$ & $\begin{array}{l}\text { Lulu, Goat, } \\
\text { Sheep, Horse, } \\
\text { Mule, Dzopa }\end{array}$ & - \\
\hline 24 & TAKCHENEN & Chuksang & $7.87 \mathrm{Km}^{2}$ & $\begin{array}{l}\text { Summer + } \\
\text { Spring }\end{array}$ & $\begin{array}{l}\text { Goat, Sheep, } \\
\text { Horse, Mule, } \\
\text { Dzopa }\end{array}$ & - \\
\hline 25 & SUKCHINEN & Chuksang & $35.81 \mathrm{Km}^{2}$ & $\begin{array}{l}\text { Summer }+ \\
\text { Spring }\end{array}$ & $\begin{array}{l}\text { Goat, } \\
\text { Horse, } \\
\text { Dzopale, }\end{array}$ & - \\
\hline 26 & CHEPTIGHANG & Chuksang & $1.20 \mathrm{Km}^{2}$ & Continuous & $\begin{array}{l}\text { Lulu, Goat, } \\
\text { Sheep, Horse, } \\
\text { Mule, Dzopa }\end{array}$ & - \\
\hline 27 & BHRIGULHA & Chuksang & $8.66 \mathrm{Km}^{2}$ & Continuous & $\begin{array}{l}\text { Lulu, Goat, } \\
\text { Sheep, Horse, } \\
\text { Mule, Dzopa }\end{array}$ & $\begin{array}{l}\text { Tetang can also use } \\
\text { for grazing but } \\
\text { cannot collect dung }\end{array}$ \\
\hline 28 & CHYOGAAM & Surkhang & $3.26 \mathrm{Km}^{2}$ & Continuous & $\begin{array}{l}\text { Lulu, Goat, } \\
\text { Sheep, Horse, } \\
\text { Mule, Dzopa }\end{array}$ & $\begin{array}{l}\text { Chaile can also use } \\
\text { for grazing but } \\
\text { cannot collect dung. }\end{array}$ \\
\hline 29 & TARAHAUWA & Surkhang & $6.94 \mathrm{Km}^{2}$ & Winter & $\begin{array}{l}\text { Lulu, Goat, } \\
\text { Sheep, Horse, } \\
\text { Mule, Dzopa }\end{array}$ & $\begin{array}{l}\text { Chaile also uses this } \\
\text { pasture }\end{array}$ \\
\hline 30 & SANGBA & Surkhang & $1.64 \mathrm{Km}^{2}$ & Summer & $\begin{array}{l}\text { Lulu, Goat, } \\
\text { Sheep, Horse, } \\
\text { Mule, Dzopa }\end{array}$ & $\begin{array}{l}\text { Chaile can also use } \\
\text { for grazing but } \\
\text { cannot collect dung. }\end{array}$ \\
\hline 31 & POGO CHHYUME & Surkhang & $4.78 \mathrm{Km}^{2}$ & Continuous & $\begin{array}{l}\text { Lulu, Goat, } \\
\text { Sheep, Horse, } \\
\text { Mule, Dzopa }\end{array}$ & $\begin{array}{l}\text { Chaile can also use } \\
\text { for grazing but } \\
\text { cannot collect dung. }\end{array}$ \\
\hline 32 & PUNAMLHE & Surkhang & $5.49 \mathrm{Km}^{2}$ & Winter & $\begin{array}{l}\text { Lulu, Goat, } \\
\text { Sheep, Horse, } \\
\text { Mule, Dzopa }\end{array}$ & $\begin{array}{l}\text { Chaile can also use } \\
\text { for grazing but } \\
\text { cannot collect dung. }\end{array}$ \\
\hline 33 & $\begin{array}{l}\text { JHOKICHHYUMB } \\
\text { A }\end{array}$ & Surkhang & $6.01 \mathrm{Km}^{2}$ & Spring & $\begin{array}{l}\text { Lulu, Goat, } \\
\text { Sheep, Horse, } \\
\text { Mule, Dzopa }\end{array}$ & $\begin{array}{l}\text { Chaile can also use } \\
\text { but cannot keep } \\
\text { goth }\end{array}$ \\
\hline 34 & IMBUK & Surkhang & $7.28 \mathrm{Km}^{2}$ & Summer & $\begin{array}{l}\text { Lulu, Goat, } \\
\text { Sheep, Horse, } \\
\text { Mule, Dzopa }\end{array}$ & - \\
\hline 35 & JHACHIU & Surkhang & $4.93 \mathrm{Km}^{2}$ & Summer & $\begin{array}{l}\text { Lulu, Goat, } \\
\text { Sheep, Horse, } \\
\text { Mule, Dzopa }\end{array}$ & $\begin{array}{l}\text { Tange also uses but } \\
\text { not allowed to keep } \\
\text { goth. }\end{array}$ \\
\hline 36 & KYUTEN 1 & Chuksang & $1.15 \mathrm{Km}^{2}$ & Continuous & $\begin{array}{l}\text { Lulu, Goat, } \\
\text { Sheep, Horse, } \\
\text { Mule, Dzopa }\end{array}$ & $\begin{array}{l}\text { Chaile can use and } \\
\text { can also keep goth }\end{array}$ \\
\hline
\end{tabular}


A. Pokhrel and M. Chetri / Our Nature (2006)4:29-41

\begin{tabular}{|c|c|c|c|c|c|c|}
\hline 37 & $\begin{array}{l}\text { CHHUNSI } \\
\text { DANDA }\end{array}$ & Chuksang & $3.55 \mathrm{Km}^{2}$ & Summer & $\begin{array}{l}\text { Lulu, Goat, } \\
\text { Sheep, Horse, } \\
\text { Mule, Dzopa }\end{array}$ & $\begin{array}{l}\text { Chaile can use and } \\
\text { can also keep goth. } \\
\text { Near to Chhunsi } \\
\text { Gomba. }\end{array}$ \\
\hline 38 & TAMSYAL & Chuksang & $0.92 \mathrm{Km}^{2}$ & Continuous & $\begin{array}{l}\text { Lulu, Goat, } \\
\text { Sheep, Horse, } \\
\text { Mule, Dzopa }\end{array}$ & $\begin{array}{l}\text { Chaile can use and } \\
\text { can also keep goth. } \\
\text { Location of old } \\
\text { chuksang village. }\end{array}$ \\
\hline 39 & CHHYUME & Chuksang & $3.69 \mathrm{Km}^{2}$ & Continuous & $\begin{array}{l}\text { Lulu, Goat, } \\
\text { Sheep, Horse, } \\
\text { Mule, Dzopa }\end{array}$ & $\begin{array}{l}\text { Chaile can use for } \\
\text { grazing and cutting } \\
\text { fuelwood. }\end{array}$ \\
\hline 40 & VENYA & Chuksang & $2.10 \mathrm{Km}^{2}$ & Continuous & $\begin{array}{l}\text { Lulu, Goat, } \\
\text { Sheep, Horse, } \\
\text { Mule, Dzopa }\end{array}$ & $\begin{array}{l}\text { Chaile can use for } \\
\text { grazing and cutting } \\
\text { fuelwood. }\end{array}$ \\
\hline 41 & TALLO VENYA & Chuksang & $0.86 \mathrm{Km}^{2}$ & Continuous & $\begin{array}{l}\text { Lulu, Goat, } \\
\text { Sheep, Horse, } \\
\text { Mule, Dzopa }\end{array}$ & - \\
\hline 42 & RUWARUWA & Chuksang & $2.06 \mathrm{Km}^{2}$ & Continuous & $\begin{array}{l}\text { Lulu, Goat, } \\
\text { Sheep, Horse, } \\
\text { Mule, Dzopa }\end{array}$ & - \\
\hline 43 & GHOKETHANG & Chuksang & $1.59 \mathrm{Km}^{2}$ & Continuous & $\begin{array}{l}\text { Lulu, Goat, } \\
\text { Sheep, Horse, } \\
\text { Mule, Dzopa }\end{array}$ & - \\
\hline 44 & KHELCHYANG & Chuksang & $1.64 \mathrm{Km}^{2}$ & Continuous & $\begin{array}{l}\text { Lulu, Goat, } \\
\text { Sheep, Horse, } \\
\text { Mule, Dzopa }\end{array}$ & - \\
\hline 45 & LUNGSUNG & Chuksang & $1.92 \mathrm{Km}^{2}$ & Continuous & $\begin{array}{l}\text { Lulu, Goat, } \\
\text { Sheep, Horse, } \\
\text { Mule, Dzopa }\end{array}$ & - \\
\hline 46 & $\begin{array}{l}\text { GHYAKARKHOL } \\
\text { A }\end{array}$ & Chuksang & $0.84 \mathrm{Km}^{2}$ & Continuous & $\begin{array}{l}\text { Lulu, Goat, } \\
\text { Sheep, Horse, } \\
\text { Mule, Dzopa }\end{array}$ & - \\
\hline 47 & SYAPCHIPU & Chuksang & $1.54 \mathrm{Km}^{2}$ & Continuous & $\begin{array}{l}\text { Lulu, Goat, } \\
\text { Sheep, Horse, } \\
\text { Mule, Dzopa }\end{array}$ & - \\
\hline 48 & CHYOHAR & Chuksang & $2.71 \mathrm{Km}^{2}$ & $\begin{array}{l}\text { Summer }+ \\
\text { Autumn }\end{array}$ & $\begin{array}{l}\text { Lulu, Goat, } \\
\text { Sheep, Horse, } \\
\text { Mule, Dzopa }\end{array}$ & - \\
\hline 49 & HYULKI PANGA & Chuksang & $5.18 \mathrm{Km}^{2}$ & Continuous & $\begin{array}{l}\text { Lulu, Goat, } \\
\text { Sheep, Horse, } \\
\text { Mule, Dzopa }\end{array}$ & - \\
\hline 50 & TAALAM & Chuksang & $3.82 \mathrm{Km}^{2}$ & Continuous & $\begin{array}{l}\text { Lulu, Goat, } \\
\text { Sheep, Horse, } \\
\text { Mule, Dzopa }\end{array}$ & - \\
\hline 51 & PIRI & Chuksang & $2.96 \mathrm{Km}^{2}$ & Summer & $\begin{array}{l}\text { Goat, Sheep, } \\
\text { Horse, Mule, } \\
\text { Dzopa }\end{array}$ & $\begin{array}{l}\text { Commonly used by } \\
\text { Chuksang and } \\
\text { Ghami VDC. The } \\
\text { word PIRI implies } \\
\text { common in local } \\
\text { language. }\end{array}$ \\
\hline
\end{tabular}




\section{A. Pokhrel and M. Chetri / Our Nature (2006)4:29-41}

survey period. Funding for this study was provided by the National Trust for Nature Conservation-Annapurna Conservation Area Project/Upper Mustang Biodiversity Conservation Project (NTNC-ACAP/UMBCP. Herders and village elites are highly acknowledged for providing us with the information. Thanks are also due to Nawa Raj Chapagain, GIS officer, NTNC-ACAP for his continuous guidance and encouragement while preparing map using GIS software.

\section{References}

Craig. S. 1996. Pasture Management, Indigenous Veterinary Care and the Role of the Horse in Mustang, Nepal. In: Rangelands and Pastoral Development in the Hindu Kush - Himalayas (Eds. D.J. Miller and S.R. Craig), ICIMOD, Kathmandu, Nepal, pp 147-170.

Chetri, M. and C.R. Gurung 2004. Vegetation Composition, species performance and its relationship among livestock and wildlife in the grassland of Upper Mustang, Nepal. In: Yak Production in Central Asian Highlands (Eds. Z. Jincheng, Z. Xiangdong, $\mathrm{H}$. Jianlin and $\mathrm{C}$. Zhihua), Proceeding of the Fourth International Congress on Yak. Sichuan Publising Group, Sichuan Publication House of Science and Technology. pp. 235-244.

Goldstein, M.C. and C. Beall 1990. Nomads of Western Tibet: The Survival of a Way of Life. Univ. California Press, Berkeley.
Kunwar, P.B. 2003. People-Wildlife conflict in the Upper Mustang of Annapurna Conservation area. Institute of Forestry, Tribhuvan University, Pokhara, Nepal. (M.Sc Thesis)

Miller, D.J. 1996. New Perspectives on Range Management, Pastoralism, and their implications for HKH-Tibetan Plateau Rangelands. In: Rangelands and Pastoral Development in the Hindu Kush - Himalayas.( Eds. D.J. Miller and S.R. Craig), Proceedings of a Regional Expert's meeting, ICIMOD, Kathmandu, Nepal, pp 7-12.

MIS, 2002: Management Information System for Upper Mustang Biodiversity Conservation Project. KMTNC-ACAP-UMBCP, Pokhara. 9.

Pokharel, A. 2006a. An assessment of Rangelands andPastoral production systems, Upper Mustang, Nepal. Institute of Forestry. (B.Sc. Thesis).

Pokharel, A. 2006b. Pasture Mapping of Upper Mustang. A Project report submitted to National Trust for Nature Conservation-Annapurna Conservation Area Project/Upper Mustang Biodiversity Conservation Project.

Schaller, G.B. and B. Gu 1994. Comparative ecology of ungulates in the Aru Basin of Northwest Tibet.National Geographic Research and Exploration 10: 266-293.

Thakali, S. 1994. Regenerating Tradition: Tourism and Cultural Invention in Nepal. Roehampton Institute, University Survey, U.K.(MA Thesis)

Wang, Y., M. Shiyomi, M. Tsuiki, X. Yu and R. Yi 2002. Spatial heterogeneity of vegetation under different grazing intensities in the Northwest Heilongjiang Steppe of China. Agriculture,Ecosystems and Environment 90: 217-229. 